University of Nebraska - Lincoln

DigitalCommons@University of Nebraska - Lincoln

Agronomy \& Horticulture -- Faculty Publications

Agronomy and Horticulture Department

2017

\title{
Metabolism of 2,4-dichlorophenoxyacetic acid contributes to resistance in a common waterhemp (Amaranthus tuberculatus) population
}

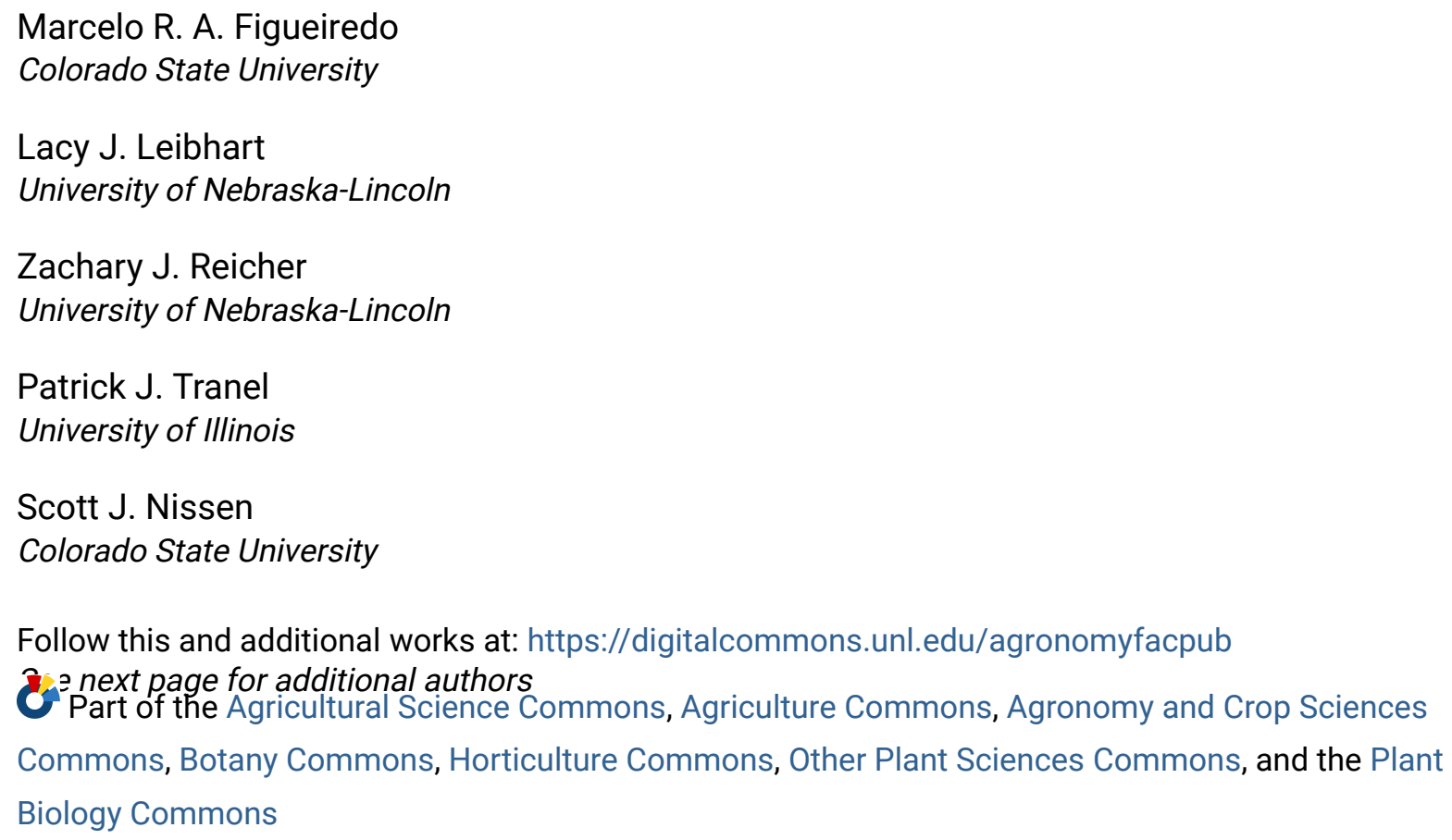

Figueiredo, Marcelo R. A.; Leibhart, Lacy J.; Reicher, Zachary J.; Tranel, Patrick J.; Nissen, Scott J.; Westra, Philip; Bernards, Mark L.; Kruger, Greg R.; Gaines, Todd A.; and Jugulam, Mithila, "Metabolism of 2,4-dichlorophenoxyacetic acid contributes to resistance in a common waterhemp (Amaranthus tuberculatus) population" (2017). Agronomy \& Horticulture -- Faculty Publications. 1057.

https://digitalcommons.unl.edu/agronomyfacpub/1057

This Article is brought to you for free and open access by the Agronomy and Horticulture Department at DigitalCommons@University of Nebraska - Lincoln. It has been accepted for inclusion in Agronomy \& Horticulture -Faculty Publications by an authorized administrator of DigitalCommons@University of Nebraska - Lincoln. 


\section{Authors}

Marcelo R. A. Figueiredo, Lacy J. Leibhart, Zachary J. Reicher, Patrick J. Tranel, Scott J. Nissen, Philip Westra, Mark L. Bernards, Greg R. Kruger, Todd A. Gaines, and Mithila Jugulam 
Metabolism of 2,4-dichlorophenoxyacetic acid contributes to resistance in a common waterhemp (Amaranthus tuberculatus) population

Marcelo R. A. Figueiredo ${ }^{\mathrm{a}}$, Lacy J. Leibhart ${ }^{\mathrm{b}}$, Zachary J. Reicher ${ }^{\mathrm{b}}$, Patrick J. Tranel ${ }^{\mathrm{c}}$, Scott J. Nissen $^{\mathrm{a}}$, Philip Westra ${ }^{\mathrm{a}}$, Mark L. Bernards ${ }^{\mathrm{d}}$, Greg R. Kruger ${ }^{\mathrm{e}}$, Todd A. Gaines ${ }^{\mathrm{a},{ }^{*}}$, and Mithila Jugulam, ${ }^{\text {f* }}$

Running title: Enhanced 2,4-D metabolism in A. tuberculatus

aDepartment of Bioagricultural Sciences and Pest Management, Colorado State University, Fort Collins, CO 80523

${ }^{b}$ Department of Agronomy and Horticulture, University of Nebraska-Lincoln, Lincoln, NE 68583

${ }^{\mathrm{c}}$ Department of Crop Sciences, University of Illinois, Urbana, IL 61801

${ }^{\mathrm{d}}$ School of Agriculture, Western Illinois University, Macomb, IL 61455

e Department of Agronomy and Horticulture, West Central Research and Extension Center, University of Nebraska-Lincoln, North Platte, NE 69101

fDepartment of Agronomy, Kansas State University, Manhattan, KS 66502

*Corresponding authors: mithila@ksu.edu and todd.gaines@colostate.edu

\section{Abstract:}

BACKGROUND: Synthetic auxins such as 2,4-D have been widely used for selective control of broadleaf weeds since the mid-1940s. In 2009, an Amaranthus tuberculatus (common

This article has been accepted for publication and undergone full peer review but has not been through the copyediting, typesetting, pagination and proofreading process, which may lead to differences between this version and the Version of Record. Please cite this article as doi: $10.1002 / \mathrm{ps} .4811$ 
waterhemp) population with 10-fold resistance to 2,4-D was found in Nebraska, USA. The 2,4-D resistance mechanism was examined by conducting $\left[{ }^{14} \mathrm{C}\right]$ 2,4-D absorption, translocation and metabolism experiments.

RESULTS: No differences were found in 2,4-D absorption or translocation between the resistant and susceptible A. tuberculatus. Resistant plants metabolized $\left[{ }^{14} \mathrm{C}\right] 2,4-\mathrm{D}$ more rapidly than did susceptible plants. The half-life of $\left[{ }^{14} \mathrm{C}\right]$ 2,4-D in susceptible plants was $105 \mathrm{~h}$, compared to $22 \mathrm{~h}$ in resistant plants. Pre-treatment with the cytochrome P450 inhibitor malathion inhibited $\left[{ }^{14} \mathrm{C}\right]$ 2,4-D metabolism in resistant plants and reduced the 2,4-D dose required for 50\% growth inhibition (GR50) of resistant plants by 7-fold to $27 \mathrm{~g} \mathrm{ha}^{-1}$, similar to the $\mathrm{GR}_{50}$ for susceptible plants in the absence of malathion.

CONCLUSIONS: Our results demonstrate that rapid 2,4-D metabolism is a contributing factor to resistance in A. tuberculatus, potentially mediated by cytochrome P450. Metabolism-based resistance to 2,4-D could pose a serious challenge for A. tuberculatus control due to the potential for cross-resistance to other herbicides.

Key words: 2,4-D resistance, 2,4-D metabolism, Amaranthus tuberculatus, 2,4-D uptake and translocation, cytochrome P450. 


\section{INTRODUCTION}

The synthetic auxin herbicide 2,4-D was introduced for weed control in agriculture in the mid-1940s ${ }^{1}$ and has since become one of the most widely used herbicides in the world. This and other auxinic herbicides are popular among growers, in part because of their ability to selectively control broadleaf weeds. In 2005, the United States Environmental Protection Agency estimated annual 2,4-D use in agriculture and non-agriculture settings at 20.9 million $\mathrm{kg}^{2}$ Even after the introduction of newer herbicides, such as glyphosate, triazines, and acetolactate synthase (ALS) inhibitors, auxinic herbicide use has remained high, primarily because of their selectivity, efficacy, broad-spectrum of control, and low cost. ${ }^{1}$ More recently, the widespread and increasing evolution of resistance in weed species to various other herbicides has resulted in an increase in auxinic herbicide use. The development and commercialization of 2,4-D-resistant cotton (Gossypium hirsutum) and soybean (Glycine max) crop varieties ${ }^{3}$ will likely increase 2,4-D use for in-crop selective weed control.

Synthetic auxin herbicides are known to mimic several physiological and biochemical responses induced by the natural plant hormone, indole acetic acid (IAA). ${ }^{4}$ Despite their extensive use in agriculture for several decades, the precise mechanism of synthetic auxin herbicide action is not completely understood. Upon discovery of IAA receptors Transport Inhibitor Response 1 (TIR1) and Auxin F-Box (AFB) proteins, ${ }^{5,6}$ the role of these proteins in auxinic herbicide-mediated responses has also been examined. ${ }^{7,8}$ One hypothesis is that functional redundancy in auxin receptors (i.e., TIR1 and AFBs 1-5) might contribute to multiple sites of action for auxinic herbicides. The precise role of these proteins in auxinic herbicidemediated responses is still elusive. Previous research also suggests that auxinic herbicides 
activate metabolic processes that initiate ethylene accumulation, resulting in epinasty. ${ }^{4}$ Other factors potentially leading to plant death include abscisic acid (ABA) accumulation resulting in 1) photosynthesis inhibition, 2) $\mathrm{H}_{2} \mathrm{O}_{2}$ production, and 3) increase in reactive oxygen species (ROS). ${ }^{4,9}$

The selectivity of auxinic herbicides in controlling broadleaf species is primarily due to auxinic herbicide metabolism by tolerant species. ${ }^{10}$ Metabolism also plays a key role in conferring resistance to these herbicides in dicot species as well. ${ }^{11}$ In most cases, auxinic herbicides undergo oxidation, hydrolysis, or conjugation resulting in reduced biological activity. ${ }^{11-13}$ In tolerant monocots, metabolic reactions typically occur through ring hydroxylation followed by irreversible glucose conjugation. ${ }^{14}$ In sensitive dicots, auxinic herbicides may be conjugated to amino acids, which are reversible to active forms and may still have partial herbicidal activity themselves. ${ }^{15}$

Amaranthus tuberculatus (Moq.) Sauer var. rudis (Sauer) Costea and Tardif (common waterhemp) is a major troublesome weed of cropping systems in North America. ${ }^{16}$ Especially in agricultural fields of the Midwestern United States, this weed poses a serious problem causing significant yield losses in maize (Zea mays) and soybean. ${ }^{17-20}$ A. tuberculatus is dioecious and a prolific seed producer, which enables rapid spread. ${ }^{20}$ High genetic variability coupled with intense herbicide selection pressure has resulted in evolution of resistance to several commonly used herbicides in A. tuberculatus. ${ }^{21-23}$ US Midwestern populations of A. tuberculatus have various combinations of herbicide resistance spanning six modes of action including photosystem II (PSII)-inhibitors, ALS-inhibitors, protoporphyrinogen oxidase (PPO) inhibitors, 4-hydroxyphenylpyruvate dioxygenase (HPPD) inhibitors, 5-enolpyruvylshikimate-3-phosphate synthase (EPSPS) inhibitors, and 2,4-D. ${ }^{24}$ 
Herbicide resistance has become a major global issue and numerous agriculturally important weeds have confirmed resistance to multiple herbicide modes of action. ${ }^{24}$ Even after several decades of continuous auxinic herbicide use, the rate of resistance evolution to auxinic herbicides is comparatively low. ${ }^{25}$ There are currently 34 weed species known to have evolved resistance to auxinic herbicides, ${ }^{24}$ including A. tuberculatus. In 2009, the first failure to control A. tuberculatus with 2,4-D was reported in Nebraska, USA. This population was confirmed to have evolved resistance to 2,4-D with a resistance ratio of 10 relative to a susceptible population. ${ }^{26}$ The resistance mechanism in this A. tuberculatus population has not been determined. The objective of this research was to examine $\left[{ }^{14} \mathrm{C}\right]$ 2,4-D uptake, translocation, and metabolism in an effort to identify the resistance mechanism.

\section{MATERIALS AND METHODS}

The 2,4-D-resistant A. tuberculatus from southeast Nebraska was used in this research. ${ }^{26}$ This population was found in a seed production field of little bluestem (Schizachyrium scoparia Michx. Nash) that had been in no-till management with annual application of 2,4-D for over 10 years. The 2,4-D resistant A. tuberculatus seed was collected from the field followed by one generation of 2,4-D selection in the greenhouse to produce the seed used in these studies. An A. tuberculatus population from Nebraska known to be susceptible to 2,4-D was also used for comparison.

\section{$2.1\left[{ }^{14} \mathrm{C}\right]$ 2,4-D Absorption and Translocation}

Resistant and susceptible A. tuberculatus seeds were planted on potting soil, kept in a $4^{\circ} \mathrm{C}$ room for one week and then transferred to a greenhouse with controlled conditions at $25{ }^{\circ} \mathrm{C}$ and $75 \% \mathrm{RH}$ until reaching $8 \mathrm{~cm}$ or 4 true leaves. Plants were then transplanted to fine washed silica, 
irrigated with fertilizer ( $0.05 \%$ Miracle-Gro solution, Scotts Miracle-Gro Company, Marysville, $\mathrm{OH}$ ), and transferred to a growth chamber under the same conditions as the greenhouse except for the lighting, which was supplied with fluorescent and incandescent light.

Plants were treated at the stage of 4-6 true leaves (1 wk after transplanting). The fourth true leaf was marked and covered with aluminum foil. Plants were then sprayed in a single nozzle overhead track sprayer (DeVries Generation III Research Sprayer, Hollandale, MN, USA) with $500 \mathrm{~g} \mathrm{ha}^{-1} 2,4-\mathrm{D}\left(2,4-\mathrm{D}\right.$ amine, $455 \mathrm{~g} \mathrm{~L}^{-1}$, DuPont) in a water volume of $224 \mathrm{~L} \mathrm{ha}^{-1}$ containing $1 \%$ COC. The aluminum foil was then removed and a solution of $\left[{ }^{14} \mathrm{C}\right]-2,4-\mathrm{D}$ mixed with formulated 2,4-D and COC was applied using 10 droplets of $1 \mu \mathrm{l}$ each, so that the treated leaf received the same amount of herbicide as the rest of the plant $\left(5 \mu \mathrm{g} \mathrm{cm}^{-2}\right.$ and $\left.3 \mu 1 \mathrm{~cm}^{-2}\right)$. Total radioactivity applied per plant was $3.33 \mathrm{KBq}$ (200,000 dpm). Three replications per time point were used, and the experiment was repeated.

Evaluation time points were at $12,24,48,96$, and 192 HAT. The treated leaves were cut and washed with $5 \mathrm{ml}$ of $10 \%$ methanol and $1 \%$ NIS washing solution. The leaf rinse solution was mixed with $10 \mathrm{ml}$ of scintillation cocktail (Ecoscint $\left.{ }^{\mathrm{TM}} \mathrm{XR}\right)$ and measured for radioactivity using LSS (Packard Tri-carb 2300TR). Roots were washed with $10 \mathrm{ml}$ water, and $3 \mathrm{ml}$ of the wash solution was measured with LSS. Plants including treated leaves were pressed in newspaper and dried in a $60^{\circ} \mathrm{C}$ oven for $72 \mathrm{~h}$ before exposure to Phosphor Screen film for $3 \mathrm{~d}$ followed by imaging with a Typhoon Trio Imager (GE Healthcare). The dried tissue was separated into treated leaf, untreated leaves, stem, and roots, and then oxidized in a Biological oxidizer (OX500) followed by radioactivity measurement with LSS. The proportion of absorbed herbicide was calculated using the following equation:

$\% H_{\text {abs }}=\left[\left({ }^{14} \mathrm{Cot}\right) /\left({ }^{14} \mathrm{C}\right.\right.$ ot $+{ }^{14} \mathrm{C}$ wl $\left.)\right] \times 100$ 


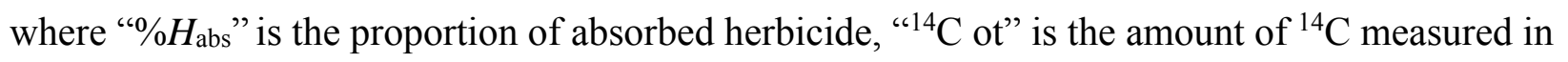
oxidized tissue, and " ${ }^{114} \mathrm{C}$ wl" is the amount of ${ }^{14} \mathrm{C}$ detected in the treated leaf. For herbicide translocation studies the following equation was used:

$\% H_{\text {tr }}=100-\left[\left({ }^{14} \mathrm{C} \mathrm{al}\right) /\left({ }^{14} \mathrm{C} \mathrm{al}+{ }^{14} \mathrm{C}\right.\right.$ ot $\left.) \times 100\right]$

where " $\% H_{\text {tr }} "$ is the proportion of translocated herbicide, ${ }^{~}{ }^{14} \mathrm{C}$ al" is the amount of ${ }^{14} \mathrm{C}$ measured in the treated leaf, and " ${ }^{114} \mathrm{C}$ ot" is the amount of ${ }^{14} \mathrm{C}$ detected in other untreated tissues of the plant.

\section{$2.2\left[{ }^{14} \mathrm{C}\right]$ Metabolism}

Plants were treated with the same procedures and conditions as the absorption and translocation studies. They were harvested at 12, 24, 48, 96, 192, and 264 HAT and at each time point, treated leaf, roots, and sand were washed and the plant tissue was rapidly frozen in liquid nitrogen and stored at $-80{ }^{\circ} \mathrm{C}$. Metabolite extraction was performed by grinding the entire plant with a mortar and pestle, then digesting tissue with a $10 \mathrm{ml}$ solution of $1 \%$ acetic acid in $50 \mathrm{ml}$ plastic tubes on a table shaker for $10 \mathrm{~min}$. Extracts were put in $50 \mathrm{ml}$ centrifuge filters with $25 \mathrm{ml}$ microfiltration membranes (pore size of $0.45 \mu \mathrm{m}$ ), then the tissue digestion step was repeated two more times. Filters and tissue were dried and kept for oxidation to quantify the non-extracted metabolites. Final extracted volume of $30 \mathrm{ml}$ was applied to a solid phase extraction $\mathrm{C} 18$ cartridge, and $5 \mathrm{ml}$ of digestion solution that passed through the cartridge was quantified by LSS. About $95 \%$ of radioactivity interacted with the silica matrix and was recovered with $4 \mathrm{ml}$ of acetonitrile and dried in an evaporation system under vacuum at $40{ }^{\circ} \mathrm{C}$. Entire extracts were suspended in $225 \mu \mathrm{l}$ of HPLC A solvent and filtered in $1.5 \mathrm{ml}$ centrifuge tubes with $0.4 \mu \mathrm{m}$ 
microfiltration membranes at $12,000 \times \mathrm{g}$. Filtered solution $(200 \mu \mathrm{l})$ was used for HPLC (Hitachi Instruments, Inc., San Jose, CA) using a C18 $4.6 \mathrm{~mm}$ by $150 \mathrm{~mm}$ column (C18 Column, Zorbax Eclipse XDB-C18, Agilent Technologies, Santa Clara, CA, USA), attached to a radio-detector (FlowStar LB 513, Berthold Technologies GmbH \& Co.) with a flow cell YG-150-U5D solid cell YG-Scintillator (150 $\mu$ l). Mobile Phase A contained $89.9 \%$ water, $10 \%$ acetonitrile, and $0.1 \%$ formic acid and phase B contained $99.9 \%$ acetonitrile and $0.1 \%$ formic acid. A calibration curve for radioactivity detection was constructed using a series of different counts of $\left[{ }^{14} \mathrm{C}\right]-2,4-\mathrm{D}$ (8.3 Bq, 16.7 Bq, 83.3 Bq, 166.7 Bq, 1666.7 Bq, and 3333.3 Bq). The proportion of 2,4-D metabolism was calculated using the equation:

$\% 2,4-D_{\text {Parent }}=[($ HPLC detected 2,4-D) $/($ HPLC detected 2,4-D + HPLC detected metabolites + counts in oxidized filters + counts in digestion solution after $\mathrm{C} 18$ cartridge separation + counts in washed sand) $] \times 100$ where “\%2,4- Dearent" is the proportion of non-metabolized herbicide. The experiment had 3 replications and it was repeated.

\subsection{Malathion Effects on 2,4-D Resistance and Metabolism}

Resistant and susceptible A. tuberculatus plants were grown in a greenhouse under controlled conditions as described above, except that plants were grown in potting soil. Half of the resistant and susceptible plants were treated with malathion (Spectracide, United Industries Corporation, St. Louis, MO) at 2,000 $\mathrm{g} \mathrm{ha}^{-1}, 24 \mathrm{~h}$ before 2,4-D treatment. Plants were treated with 2,4-D (2,4-D amine, $455 \mathrm{~g} \mathrm{~L}^{-1}$, DuPont) at the developmental stage of 4-5 true leaves and treatments were $0,15,30,63,125,250,500,1,000,2,000$, and 6,000 $\mathrm{g} \mathrm{ha}^{-1}$. Plants were harvested $28 \mathrm{~d}$ after treatment and dried in a $60{ }^{\circ} \mathrm{C}$ oven before weighing. 
Another study to analyze malathion effects on 2,4-D metabolism was conducted as described above. Half of the plants transplanted to fine silica were sprayed with malathion at 2,000 $\mathrm{g} \mathrm{ha}^{-1}$, and at $24 \mathrm{HAT}$ all resistant and susceptible plants were treated with $\left[{ }^{14} \mathrm{C}\right] 2,4-\mathrm{D}$ as described above. After $264 \mathrm{~h},\left[{ }^{14} \mathrm{C}\right] 2,4-\mathrm{D}$ treated leaves and roots were washed and the tissue was frozen with liquid nitrogen for metabolite extraction as described above. The amount of 2,4D recovered was calculated using the equation "\%2,4- DParent" described above. Each treatment had 3 replications and the experiment was repeated.

\subsection{Data Analysis}

The experiments were analyzed using the software $\mathrm{R} .{ }^{28}$ Absorption and translocation over time were analyzed using a rectangular hyperbolic model. ${ }^{29}$ 2,4-D metabolism and 2,4-D dose response with malathion were analyzed using a three-parameter log-logistic model.$^{30}$ Malathion effect on 2,4-D metabolism was analyzed using a factorial ANOVA in R and contrast comparisons were adjusted by the Tukey method.

\section{RESULTS}

\section{1 $\left[{ }^{14} \mathrm{C}\right]$ 2,4-D Absorption and Translocation}

To investigate the 2,4-D resistance mechanisms in A. tuberculatus, we first determined if reduced absorption or translocation of $\left[{ }^{14} \mathrm{C}\right] 2,4-\mathrm{D}$ contributed to resistance. There were no differences in the amount of $\left[{ }^{14} \mathrm{C}\right] 2,4-\mathrm{D}$ absorbed between 2,4-D-resistant or -susceptible plants at all harvest times (Figure 1A, Supporting Information Tables 1 and 2). No difference was found in $\mathrm{A}_{\max }$ (maximum absorption) between populations (S: 73\% \pm 4 and R: 73\% \pm 4 ) (Figure 1A), or in t90 (time in $\mathrm{h}$ for $90 \%$ of maximum absorption) between populations ( $\mathrm{S}: 43 \mathrm{~h} \pm 4$ and $\mathrm{R}: 33 \mathrm{~h} \pm 7)$. 
2,4-D is a systemic herbicide that translocates via xylem and phloem to other parts of the plant following absorption. Translocation was similar between resistant and susceptible plants through 96 HAT (Figure 1B, Supporting Information Tables 1 and 2). Although the experiment was conducted over a reasonable time course of $192 \mathrm{~h}, 2,4-\mathrm{D}$ translocation in resistant plants did not reach an asymptote by the last time point. The $\mathrm{T}_{192}$ value (translocation at $192 \mathrm{HAT}$ ) was higher in resistant plants $(42 \mathrm{~h} \pm 9)$ than in susceptible plants $(23 \mathrm{~h} \pm 6)$. This suggests 2,4-D translocation in susceptible plants is self-limiting beyond 96 HAT when plant death occurs, while 2,4-D translocation continues in resistant plants. Phosphor images confirmed no differences in translocation between the two populations through 96 HAT (Figure 1C). Therefore, differences in 2,4-D absorption or translocation do not contribute substantially to 2,4D resistance in this A. tuberculatus population.

\section{2 $\left[{ }^{14} \mathrm{C}\right]$ 2,4-D Metabolism}

To determine if 2,4-D metabolism was a factor in the resistance mechanism of this $A$. tuberculatus population, we measured how much $\left[{ }^{14} \mathrm{C}\right] 2,4-\mathrm{D}$ was metabolized over time. The parent compound of $\left[{ }^{14} \mathrm{C}\right] 2,4-\mathrm{D}$ resolved at peak retention time (RT) of about $12.5 \mathrm{~min}$ by reverse-phase HPLC with no other peaks observed (data not shown). This indicates that peaks at other retention times observed in plant lysates are products derived from 2,4-D metabolism (Figures 2A, B). At 264 HAT, a large amount of 2,4-D was detected and just one main metabolite was produced in susceptible plants (metabolite 1), at RT of 10.40 min (Figure 2A). In resistant plants, a small 2,4-D peak was detected and another main metabolite was produced at RT of 8 min (metabolite 4, Figure 2B). Additional metabolites were also detected, including metabolite 1 also found in susceptible plants, metabolite $2(\mathrm{RT}=9.5 \mathrm{~min})$, metabolite $3(\mathrm{RT}=$ $8.7 \mathrm{~min})$, metabolite $5(\mathrm{RT}=7 \mathrm{~min})$, and metabolite $6(\mathrm{RT}=2 \mathrm{~min})$ (Figure $2 \mathrm{~B})$. Analyzing 
metabolism over time using a log-logistic model (Figure 2C, Supporting Information Table 1) showed that resistant plants had a 2,4-D half-life (time to reach 50\% 2,4-D metabolism) of $22 \mathrm{~h}$ \pm 4 , five times faster than susceptible plants $(105 \mathrm{~h} \pm 7)$. The time to reach $70 \% 2,4$-D metabolism in resistant plants was $54 \mathrm{~h} \pm 4$, and $307 \mathrm{~h} \pm 36$ for susceptible plants. From these results, it is evident that the resistant A. tuberculatus plants rapidly metabolize 2,4-D (Supporting Information Table 3).

\subsection{Malathion Effects on 2,4-D Resistance and Metabolism}

To test the hypothesis that enhanced 2,4-D metabolism was conferred by cytochrome P450, the known cytochrome P450-inhibitor malathion was tested. The 2,4-D dose required to reduce growth by $50 \%\left(\mathrm{GR}_{50}\right)$ in resistant plants in the absence of malathion was $176 \mathrm{~g} \mathrm{ha}^{-1} \pm 37$, eight times higher than the $\mathrm{GR}_{50}$ for susceptible plants $\left(22 \mathrm{~g} \mathrm{ha}^{-1} \pm 5\right)$. Pre-treatment with malathion followed by 2,4-D dose response resulted in the resistant population having a 7-fold reduction in $\mathrm{GR}_{50}$ compared to no pre-treatment and a similar 2,4-D response as the susceptible population (Figure 3A, Supporting Information Table 1). With malathion pre-treatment, the GR 50 for resistant plants was $27 \mathrm{~g} \mathrm{ha}^{-1} \pm 10$, similar to the $\mathrm{GR}_{50}$ for susceptible plants following malathion pre-treatment $\left(22 \mathrm{~g} \mathrm{ha}^{-1} \pm 3\right)$.

To investigate whether malathion affected 2,4-D metabolism, malathion treated and untreated plants were treated with $\left[{ }^{14} \mathrm{C}\right] 2,4-\mathrm{D}$ and harvested 264 HAT. Malathion reduced 2,4-D

metabolism in both resistant and susceptible populations (Figure 3B). With 2,4-D treatment only, susceptible plants had $25 \%$ of the parent 2,4-D remaining at 264 HAT while resistant plants had 7\% parent 2,4-D remaining. Following malathion treatment, the resistant and susceptible populations had similar amounts ( $73 \%$ and $74 \%$, respectively) of parent $2,4-\mathrm{D}$ remaining at 264 HAT (Figure 3B, Supporting Information Table 1). 


\section{DISCUSSION}

\subsection{Metabolism of 2,4-D primarily contributes to 2,4-D resistance in A. tuberculatus}

Auxinic herbicides were the first chemical family of selective herbicides to be discovered and are the most widely used selective herbicides. The phenoxy herbicide 2,4-D is effective in controlling a number of broadleaf weeds including A. tuberculatus. Herbicide resistance mechanisms have been categorized into two types, a) non-target-site, involving decreased absorption, translocation and/or enhanced herbicide metabolism, and b) target-site, resulting from mutations in the target gene or increased levels of the target protein by gene amplification or transcriptional upregulation. ${ }^{31}$ Previous research found that auxinic herbicide resistance in wild mustard (Sinapis arvensis), ${ }^{32}$ false cleavers (Galium spurium), ${ }^{33}$ kochia (Kochia scoparia), ${ }^{34}$ and yellow starthistle (Centaurea solstitialis) ${ }^{35,36}$ was not due to differences in herbicide absorption, translocation and/or metabolism and, by deduction, might be due to other mechanisms, such as altered target site. A different dicamba-resistant $K$. scoparia population was found to have reduced dicamba translocation. ${ }^{37}$

In this research, 2,4-D resistance was investigated by determining $\left[{ }^{14} \mathrm{C}\right]$ 2,4-D uptake, translocation, and metabolism in resistant and susceptible A. tuberculatus populations from NE. Our results indicate that 2,4-D absorption and translocation were similar between resistant and susceptible A. tuberculatus, and therefore do not appear to contribute to resistance. Previously, a similar amount of total 2,4-D absorption and translocation was reported in leafy spurge (Euphorbia esula) and cucumber (Cucumis sativus). ${ }^{38,39}$ However, in 2,4-D susceptible ground ivy (Glechoma hederacea), 37\% more 2,4-D was absorbed than in resistant plants. ${ }^{40}$ In a Jimsonweed (Datura stramonium) population susceptible to 2,4-D, about $70 \%$ of the absorbed 2,4-D was translocated within the plant. ${ }^{41}$ Reduced MCPA (phenoxy herbicide) translocation 
was found in resistant hemp-nettle (Galeopsis tetrahit) compared to susceptible. ${ }^{42}$ Recently, reduced 2,4-D translocation was found to confer resistance in a wild radish (Raphanus raphanistrum) population. ${ }^{43}$ However, in another wild radish population resistant to MCPA, it was found that the resistant plants translocated MCPA more rapidly to roots than did susceptible plants, and also less $\left[{ }^{14} \mathrm{C}\right] \mathrm{MCPA}$ (as \% applied) was recovered in resistant plants than in susceptible plants at 48 and $72 \mathrm{HAT} .{ }^{44}$ In that study, $\left[{ }^{14} \mathrm{C}\right] \mathrm{MCPA}$ was translocated to the roots, but in A. tuberculatus, most of the translocated radioactivity was found in the foliage and very little in the roots. The higher translocation observed in resistant A. tuberculatus at 264 HAT may be related to the possible greater mobility of 2,4-D metabolites than parent 2,4-D, as well as the possibility of self-limiting translocation in susceptible plants once plant death occurs.

Our results show that enhanced 2,4-D metabolism contributes to resistance in the $A$. tuberculatus population from NE. The susceptible plants had higher parent $\left[{ }^{14} \mathrm{C}\right] 2,4-\mathrm{D}$ remaining at all time points. The model of 2,4-D metabolism over time showed that resistant plants metabolized 2,4-D seven times faster than did susceptible plants. Previously, 2,4-Dsusceptible hemp dogbane (Apocynum cannabinum) was found to metabolize only $48 \%$ of the herbicide at $12 \mathrm{~d}$ after application. ${ }^{45}$ Euphorbia esula plants susceptible to 2,4-D contained 85\% of the parent $\left[{ }^{14} \mathrm{C}\right] 2,4-\mathrm{D}$ at $72 \mathrm{HAT} .{ }^{38}$ One study reported elevated 2,4-D metabolism in lesssusceptible wild cucumber when compared to more-susceptible cultivated cucumber. ${ }^{39}$ An MCPA-resistant G. tetrahit population had increased MCPA metabolism compared to a susceptible population. ${ }^{42}$ The bacterial aryloxyalkanoate dioxygenase transformed in 2,4-D resistant crops show that rapid 2,4-D metabolism can confer robust 2,4-D resistance. ${ }^{3}$ Collectively these results suggest that if enough 2,4-D is metabolized in A. tuberculatus from 24- 
48 HAT, the enhanced metabolism will enable the resistant plant to survive short-term 2,4-D induced toxicity and continue to grow.

Auxinic herbicide selectivity in crops is primarily dependent on plant metabolism of these herbicides. Metabolic detoxification of 2,4-D typically occurs through side-chain cleavage, or ring hydroxylation followed by glucose conjugation. Tolerant plants can convert the parent biologically active molecule to more polar and insoluble residues. ${ }^{46}$ Sensitive species can sometimes metabolize 2,4-D faster than tolerant species, however, the main metabolites formed in sensitive species are reversible conjugates that can rapidly convert back to the biologically active, parent compound. ${ }^{47}$ The metabolites produced by tolerant species are generally more stable and irreversible. ${ }^{47}$ In auxinic herbicide-tolerant monocots, the formation of stable metabolites via phenyl and heterocyclic ring hydroxylation followed by subsequent sequestration of the non-biologically active compounds has been reported. ${ }^{48}$

The specific reactions involved in 2,4-D detoxification in our resistant population need to be investigated. One main metabolite was produced in susceptible plants while resistant plants produced the same metabolite with several additional metabolites. The structures of these metabolites have not yet been identified, but this information would help determine the biochemical steps involved in the enhanced 2,4-D metabolism in resistant plants. In our malathion experiments, we showed that this cytochrome P450 inhibitor reduced 2,4-D metabolism at $264 \mathrm{HAT}$ in resistant plants and reversed 2,4-D resistance in a whole-plant dose response. Cytochrome P450s are versatile enzymes involved in phase I of herbicide metabolism including ring hydroxylation, and plants have a high diversity of cytochrome P450 gene families that are able to metabolize natural and xenobiotic compounds. ${ }^{49,50}$ Many weed species have been reported with enhanced metabolic resistance mediated by cytochrome P450s to various herbicide 
modes of action including ALS, acetyl Co-A carboxylase (ACCase), photosystem II, and HPPD. ${ }^{51,52}$ Metabolic resistance in A. tuberculatus has been previously reported for ALS, ${ }^{53}$ photosystem II $^{54}$ and HPPD ${ }^{54,55}$ herbicides, with different cytochrome P450 genes likely conferring HPPD resistance in different populations. ${ }^{54,56} 2,4-\mathrm{D}$ has been reported as an inducer of cytochrome P450 activity in plants both in vitro ${ }^{57,58}$ and in vivo, ${ }^{59}$ including the induction of demethylation and ring-methyl hydroxylation of chlortoluron in tobacco (Nicotiana tabacum) cells. ${ }^{58}$ More recent studies showed that ACCase-inhibitor-susceptible Lolium plants pre-treated with 2,4-D had induction of cytochrome P450 transcripts ${ }^{60}$ and higher rates of diclofop-methyl metabolism, which was reversed after malathion treatment. ${ }^{59}$

In conclusion, these results clearly demonstrate $2,4-\mathrm{D}$ metabolism as a contributing factor for 2,4-D resistance in A. tuberculatus. Reversal of resistance and reduced 2,4-D metabolism following treatment with the cytochrome P450 inhibitor malathion indicate that one or more cytochrome P450 genes mediate this enhanced 2,4-D metabolism. Metabolism-based herbicide resistance is a particular challenge as it may confer complex and sometimes unpredictable crossresistance to current and yet-to-be-discovered herbicides. ${ }^{51,61}$

\section{ACKNOWLEDGEMENTS}

We thank Dr. Amar S. Godar and Ivan Cuvaca for technical support and statistical analysis. The work was funded in part by the Kansas Agriculture Experiment Station (Contribution 17-340-J), funding from Dow AgroSciences to Colorado State University, and the Brazilian governmental scholarship from the National Council for Scientific and Technological Development $(\mathrm{CNPq}$ 207387/2014-1) to M.F. 


\section{References}

1. Burnside OC (1996) The history of 2,4-D and its impact on development of the discipline of weed science in the United States. In: Burnside OC, editor. Biologic and economic assessment of benefits from use of phenoxy herbicides in the United States: Washington, DC: U.S. Department of Agriculture NAPIAP Rep. 1-PA-96. pp. 5-16.

2. US EPA, 2,4-D RED Facts, EPA-738-F-05-002. Available: https://www3.epa.gov/pesticides/chem_search/reg_actions/reregistration/fs_PC030001_30-Jun-05.pdf.: (2005).

3. Wright TR, Shan G, Walsh TA, Lira JM, Cui C, Song P, Zhuang M, Arnold NL, Lin G and Yau K, Robust crop resistance to broadleaf and grass herbicides provided by aryloxyalkanoate dioxygenase transgenes. Proc Natl Acad Sci USA 107: 20240-20245 (2010).

4. Grossmann K, Auxin herbicides: current status of mechanism and mode of action. Pest Manag Sci 66: 113-120 (2010).

5. Dharmasiri N, Dharmasiri S and Estelle M, The F-box protein TIR1 is an auxin receptor. Nature 435: 441 (2005).

6. Kepinski S and Leyser O, The Arabidopsis F-box protein TIR1 is an auxin receptor. Nature 435: 446 (2005).

7. Walsh TA, Neal R, Merlo AO, Honma M, Hicks GR, Wolff K, Matsumura W and Davies JP, Mutations in an auxin receptor homolog AFB5 and in SGT1b confer resistance to synthetic picolinate auxins and not to 2,4-dichlorophenoxyacetic acid or indole-3-acetic acid in Arabidopsis. Plant Physiol 142: 542-552 (2006). 
8. Gleason C, Foley RC and Singh KB, Mutant analysis in Arabidopsis provides insight into the molecular mode of action of the auxinic herbicide dicamba. PLoS One 6: e17245 (2011).

9. Grossmann K, Kwiatkowski J and Tresch S, Auxin herbicides induce $\mathrm{H} 2 \mathrm{O} 2$ overproduction and tissue damage in cleavers (Galium aparine L.). J Exp Bot 52: 1811-1816 (2001).

10. Coupland D (1994) Resistance to the auxin analog herbicides. In: Powles SB, Holtum JAM, editors. Herbicide Resistance in Plants: Biology and Biochemistry. pp. 171-214.

11. Hatzios KK and Penner D, Metabolism of herbicides in higher plants. Burgess Publishing Company.: (1982).

12. Kreuz K, Tommasini R and Martinoia E, Old enzymes for a new job (herbicide detoxification in plants). Plant Physiol 111: 349 (1996).

13. Ashton FM and Crafts AS, Mode of Action of Herbicides. Wiley. (1981).

14. Devine M, Duke SO and Fedtke C, Physiology of herbicide action. PTR Prentice Hall.: (1992).

15. Scheel D and Sandermann H, Metabolism of 2, 4-dichlorophenoxyacetic acid in cell suspension cultures of soybean (Glycine max L.) and wheat (Triticum aestivum L.). Planta 152: 253-258 (1981).

16. Trucco F and Tranel PJ (2011) Amaranthus. Wild Crop Relatives: Genomic and Breeding Resources: Springer. pp. 11-21.

17. Hager AG, Wax LM, Stoller EW and Bollero GA, Common waterhemp (Amaranthus rudis) interference in soybean. Weed Sci 50: 607-610 (2002).

18. Steckel LE, The dioecious Amaranthus spp.: here to stay. Weed Technol 21: 567-570 (2007).

19. Steckel LE and Sprague CL, Common waterhemp (Amaranthus rudis) interference in corn. Weed Sci 52: 359-364 (2004). 
20. Costea M, Weaver SE and Tardif FJ, The biology of invasive alien plants in Canada. 3. Amaranthus tuberculatus (Moq.) Sauer var. rudis (Sauer) Costea \& Tardif. Can J Plant Sci 85: 507-522 (2005).

21. Nandula VK, Ray JD, Ribeiro DN, Pan Z and Reddy KN, Glyphosate resistance in tall waterhemp (Amaranthus tuberculatus) from Mississippi is due to both altered target-site and nontarget-site mechanisms. Weed Sci 61: 374-383 (2013).

22. Lorentz L, Gaines TA, Nissen SJ, Westra P, Strek H, Dehne HW, Ruiz-Santaella JP and Beffa R, Characterization of glyphosate resistance in Amaranthus tuberculatus populations. J Agric Food Chem 62: 8134-8142 (2014).

23. Bell MS, Hager AG and Tranel PJ, Multiple resistance to herbicides from four site-of-action groups in waterhemp (Amaranthus tuberculatus). Weed Sci 61: 460-468 (2013).

24. Heap I The international survey of herbicide resistant weeds. Accessed May 23, 2017. Available on-line: www.weedscience.com. (2017).

25. Jugulam M, Hall JC, Johnson WG, Kelley KB and Riechers DE, Evolution of resistance to auxinic herbicides: historical perspectives, mechanisms of resistance, and implications for broadleaf weed management in agronomic crops. Weed Sci 59: 445-457 (2011).

26. Bernards ML, Crespo RJ, Kruger GR, Gaussoin R and Tranel PJ, A waterhemp (Amaranthus tuberculatus) population resistant to 2,4-D. Weed Sci 60: 379-384 (2012).

27. Godar AS, Varanasi VK, Nakka S, Prasad PV, Thompson CR and Jugulam M, Physiological and molecular mechanisms of differential sensitivity of Palmer amaranth (Amaranthus palmeri) to mesotrione at varying growth temperatures. PLoS One 10: e0126731 (2015). 
28. R R Core Team (2015). R: A language and environment for statistical computing. R Foundation for Statistical Computing, Vienna, Austria. URL http://www.R-project/org/. (2015).

29. Kniss AR, Vassios JD, Nissen SJ and Ritz C, Nonlinear regression analysis of herbicide absorption studies. Weed Sci 59: 601-610 (2011).

30. Knezevic SZ, Streibig JC and Ritz C, Utilizing R software package for dose-response studies: The concept and data analysis. Weed Technol 21: 840-848 (2007).

31. Powles SB and Yu Q, Evolution in action: Plants resistant to herbicides. Annu Rev Plant Biol 61: 317-347 (2010).

32. Peniuk M, Romano M and Hall J, Physiological investigations into the resistance of a wild mustard (Sinapis arvensis L.) biotype to auxinic herbicides. Weed Res 33: 431-440 (1993).

33. Van Eerd LL, Stephenson GR, Kwiatkowski J, Grossmann K and Hall JC, Physiological and biochemical characterization of quinclorac resistance in a false cleavers (Galium spurium L.) biotype. J Agric Food Chem 53: 1144-1151 (2005).

34. Cranston HJ, Kern AJ, Hackett JL, Miller EK, Maxwell BD and Dyer WE, Dicamba resistance in kochia. Weed Sci 49: 164-170 (2001).

35. Fuerst E, Sterling T, Norman M, Prather T, Irzyk G, Wu Y, Lownds N and Callihan R, Physiological characterization of picloram resistance in yellow starthistle. Pest Biochem Physiol 56: 149-161 (1996).

36. Valenzuela-Valenzuela JM, Lownds NK and Sterling TM, Clopyralid uptake, translocation, metabolism, and ethylene induction in picloram-resistant yellow starthistle (Centaurea solstitialis L.). Pest Biochem Physiol 71: 11-19 (2001). 
37. Pettinga D, Ou J, Patterson EL, Jugulam M, Westra P and Gaines TA, Transcriptomic analysis of dicamba resistance in Kochia scoparia. Pest Manag Sci: In review (2017).

38. Lym RG and Moxness KD, Absorption, translocation, and metabolism of picloram and 2, 4D in leafy spurge (Euphorbia esula). Weed Sci 37: 498-502 (1989).

39. Slife F, Key J, Yamaguchi S and Crafts A, Penetration, translocation, and metabolism of 2, 4-D and 2, 4, 5-T in wild and cultivated cucumber plants. Weeds 10: 29-35 (1962).

40. Kohler EA, Throssell CS and Reicher ZJ, 2, 4-D rate response, absorption, and translocation of two ground ivy (Glechoma hederacea) populations. Weed Technol 18: 917-923 (2004).

41. Fites R, Slife F and Hanson J, Translocation and metabolism of radioactive 2, 4-D in jimsonweed. Weeds 12: 180-183 (1964).

42. Weinberg T, Stephenson GR, McLean MD and Hall JC, MCPA (4-chloro-2ethylphenoxyacetate) resistance in hemp-nettle (Galeopsis tetrahit L.). J Agric Food Chem 54: $9126-9134$ (2006).

43. Goggin DE, Cawthray GR and Powles SB, 2,4-D resistance in wild radish: reduced herbicide translocation via inhibition of cellular transport. J Exp Bot 67: 3223-3235 (2016).

44. Jugulam M, DiMeo N, Veldhuis LJ, Walsh M and Hall JC, Investigation of MCPA (4chloro-2-ethylphenoxyacetate) resistance in wild radish (Raphanus raphanistrum L.). J Agric Food Chem 61: 12516-12521 (2013).

45. Schultz $\mathrm{M}$ and Burnside $\mathrm{O}$, Absorption, translocation, and metabolism of 2, 4-D and glyphosate in hemp dogbane (Apocynum cannabinum). Weed Sci 28: 13-20 (1980). 46. Hock B and Elstner EF, Plant toxicology. CRC Press. (2004). 
47. Peterson MA, McMaster SA, Riechers DE, Skelton J and Stahlman PW, 2, 4-D past, present, and future: a review. Weed Technol 30: 303-345 (2016).

48. Feung C-S, Hamilton RH and Mumma RO, Metabolism of 2, 4-dichlorophenoxyacetic acid. VII. Comparison of metabolites from five species of plant callus tissue cultures. J Agric Food Chem 23: 373-376 (1975).

49. Siminszky B, Plant cytochrome P450-mediated herbicide metabolism. Phytochem Rev 5: 445-458 (2006).

50. Werck-Reichhart D, Hehn A and Didierjean L, Cytochromes P450 for engineering herbicide tolerance. Trends Plant Sci 5: 116-123 (2000).

51. Yu Q and Powles S, Metabolism-based herbicide resistance and cross-resistance in crop weeds: A threat to herbicide sustainability and global crop production. Plant Physiol 166: 1106-1118 (2014).

52. Yuan JS, Tranel PJ and Stewart CN, Non-target-site herbicide resistance: a family business. Trends Plant Sci 12: 6-13 (2007).

53. Guo J, Riggins CW, Hausman NE, Hager AG, Riechers DE, Davis AS and Tranel PJ, Nontarget-site resistance to ALS inhibitors in waterhemp (Amaranthus tuberculatus). Weed Sci 63: 399-407 (2015).

54. Ma R, Kaundun SS, Tranel PJ, Riggins CW, McGinness DL, Hager AG, Hawkes T, McIndoe E and Riechers DE, Distinct detoxification mechanisms confer resistance to mesotrione and atrazine in a population of waterhemp. Plant Physiol 163: 363-377 (2013). 
55. Kaundun SS, Hutchings S-J, Dale RP, Howell A, Morris JA, Kramer VC, Shivrain VK and Mcindoe E, Mechanism of resistance to mesotrione in an Amaranthus tuberculatus population from Nebraska, USA. PloS One 12: e0180095 (2017).

56. Oliveira MC, Gaines TA, Dayan FE, Patterson EL, Jhala AJ and Knezevic SZ, Reversing resistance to tembotrione in an Amaranthus tuberculatus (var. rudis) population from Nebraska, USA with cytochrome P450 inhibitors. Pest Manag Sci: Early View (2017).

57. Adele P, Reichhart D, Salaün J-P, Benveniste I and Durst F, Induction of cytochrome P-450 and monooxygenase activity by 2, 4-dichlorophenoxyacetic acid in higher plant tissue. Plant Science Letters 22: 39-46 (1981).

58. Yamada T, Kambara Y, Imaishi H and Ohkawa H, Molecular cloning of novel cytochrome P450 species induced by chemical treatments in cultured tobacco cells. Pest Biochem Physiol 68: 11-25 (2000).

59. Han H, Yu Q, Cawthray GR and Powles SB, Enhanced herbicide metabolism induced by 2,4D in herbicide susceptible Lolium rigidum provides protection against diclofop-methyl. Pest Manag Sci 69: 996-1000 (2013).

60. Gaines TA, Lorentz L, Figge A, Herrmann J, Maiwald F, Ott MC, Han H, Busi R, Yu Q, Powles SB and Beffa R, RNA-Seq transcriptome analysis to identify genes involved in metabolism-based diclofop resistance in Lolium rigidum. Plant J 78: 865-876 (2014).

61. Délye C, Unravelling the genetic bases of non-target-site-based resistance (NTSR) to herbicides: a major challenge for weed science in the forthcoming decade. Pest Manag Sci 69: 176-187 (2013). 


\section{Figure Legends}

Figure 1. $\left[{ }^{14} \mathrm{C}\right]$-labeled 2,4-D absorption and translocation in resistant (R) and susceptible (S) $A$. tuberculatus over a $96 \mathrm{~h}$ time course (conducted at Colorado State University). A) 2,4-D absorption as percentage of applied radioactivity. B) 2,4-D translocation as percentage of absorbed radioactivity. C) Phosphor images showing 2,4-D translocation over time with the corresponding plant color image to the left of the phosphor image.

Figure 2. $\left[{ }^{14} \mathrm{C}\right]$-labeled 2,4-D metabolism in resistant and susceptible A. tuberculatus (conducted at Colorado State University). A) Susceptible and B) resistant HPLC chromatograms of $\left[{ }^{14} \mathrm{C}\right]$ 2,4-D metabolism at 264 HAT (radioactive units in Bq vs retention time in min), with different metabolites numbered in order of their respective retention times. C) Non-linear regression of 2,4-D metabolism at different time points after herbicide treatment with dashed lines indicating 2,4-D half-life.

Figure 3. Malathion reverses 2,4-D resistance and metabolism in resistant (R) and susceptible (S) A. tuberculatus. A) Dry weight dose response of $\mathrm{R}$ and $\mathrm{S}$ with and without malathion pretreatment (Mal), $28 \mathrm{~d}$ after 2,4-D application with dashed lines indicating GR 50 (2,4-D dose required to reduce biomass by 50\%). B) HPLC chromatograms of $\left[{ }^{14} \mathrm{C}\right] 2,4-\mathrm{D}$ metabolism (radioactive units in $\mathrm{Bq}$ vs retention time in $\mathrm{min}$ ) at $264 \mathrm{~h}$ after 2,4-D application in $\mathrm{R}$ and $\mathrm{S}$ with and without malathion pre-treatment. Percentage indicated above 2,4-D retention time (13.4 min) represents the mean parent $\left[{ }^{14} \mathrm{C}\right] 2,4-\mathrm{D}$ measured in all replicates. Other peaks represent 2,4-D metabolites. Letters represent significant differences between R and S (upper case) or between malathion treatments (lower case) with Tukey's test $(\mathrm{n}=6 ; \alpha=0.5)$. 

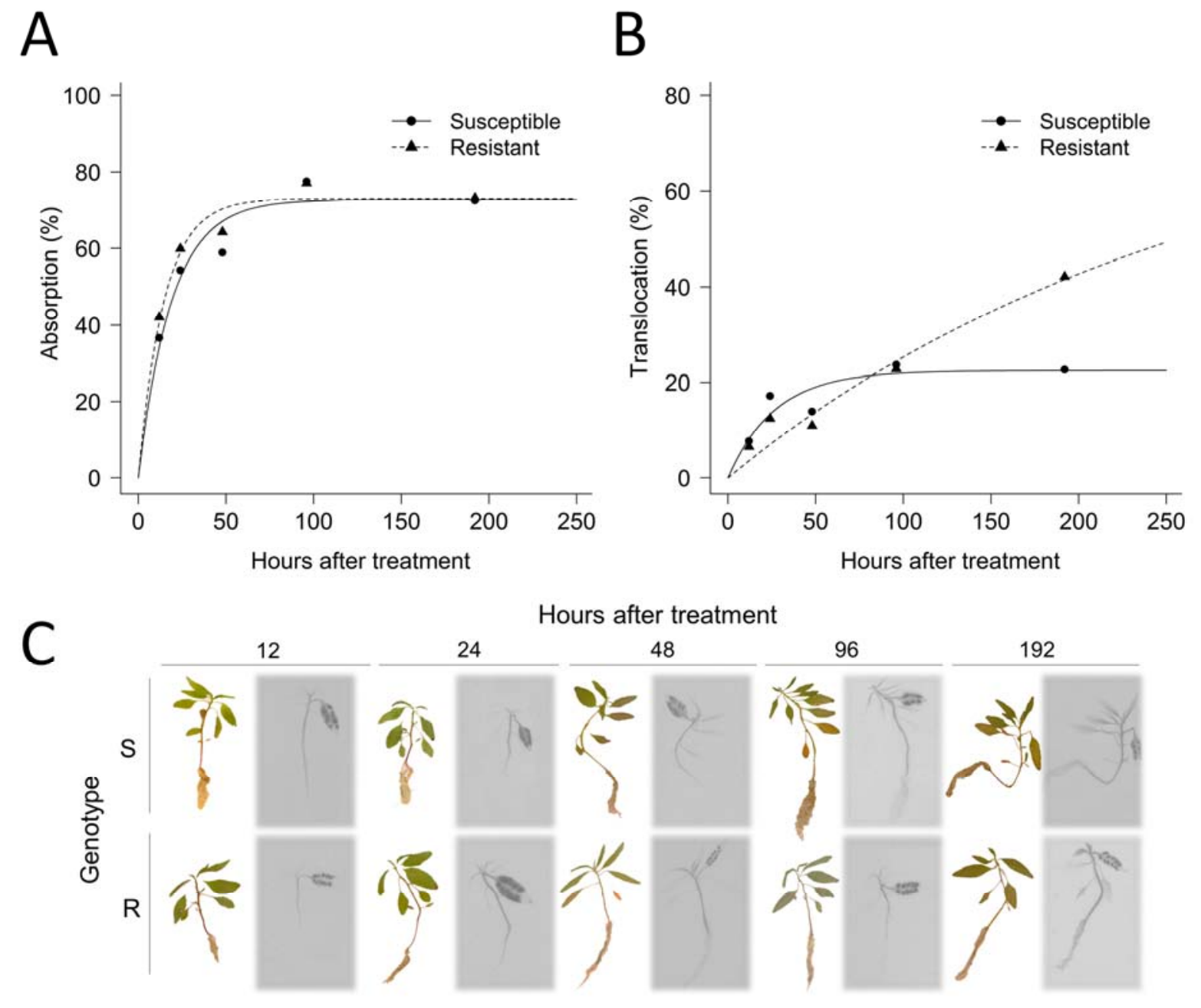

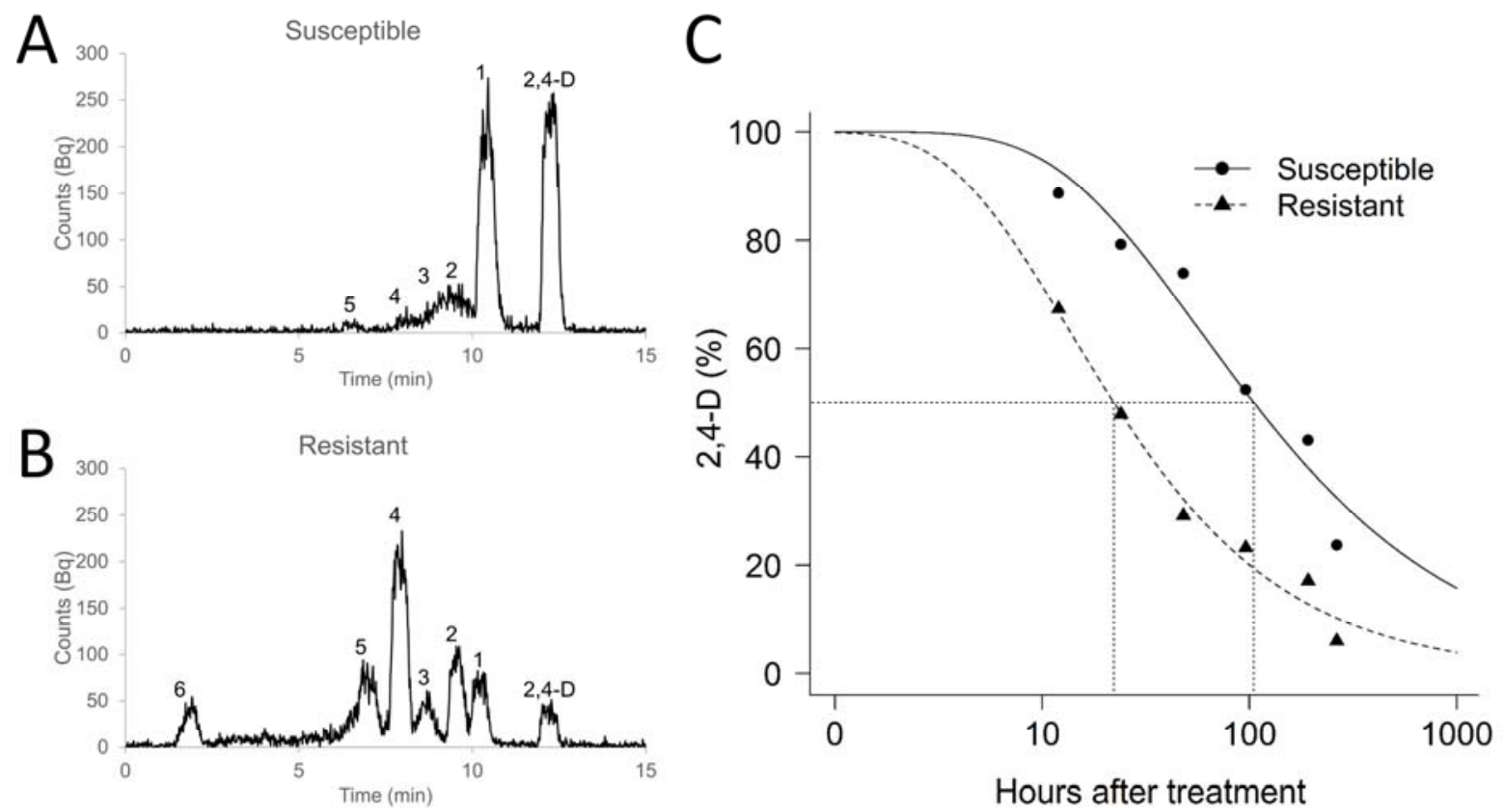

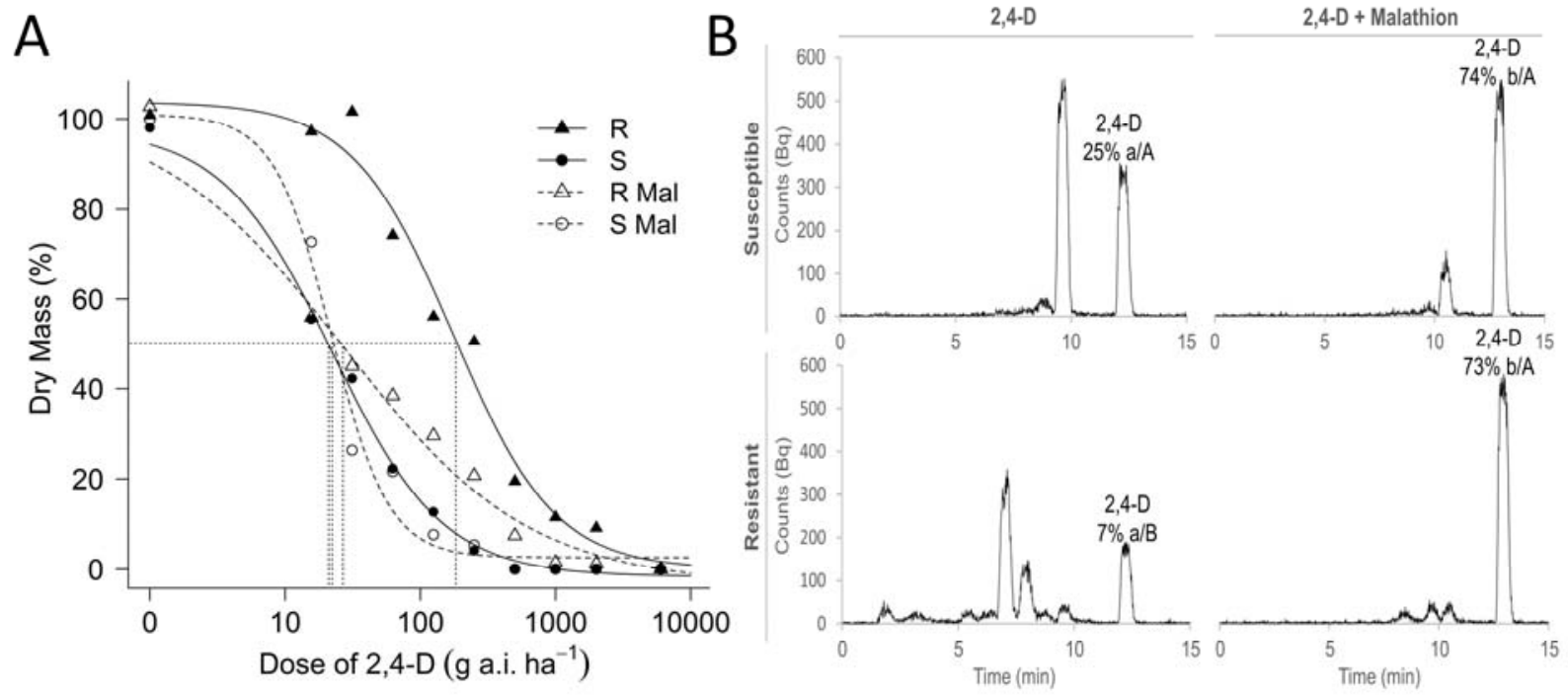


\section{SUPPORTING INFORMATION}

Metabolism of 2,4-dichlorophenoxyacetic acid contributes to resistance in a common waterhemp (Amaranthus tuberculatus) population

\section{Results}

Supporting Information Table 1. Equation parameters for $\left[{ }^{14} \mathrm{C}\right] 2,4-\mathrm{D}$ absorption, translocation, and metabolism.

\begin{tabular}{|c|c|c|}
\hline Figure & Population & Equation \\
\hline \multirow[t]{2}{*}{ 1A, absorption } & Susceptible & $f(x)=(72.6907(x)) /(0.11 * 43.2083+x)$ \\
\hline & Resistant & $f(x)=(72.9682(x)) /(0.11 * 33.4752+x)$ \\
\hline \multirow[t]{2}{*}{ 1B, translocation } & Susceptible & $f(x)=(22.4823(x)) /(0.11 * 61.3814+x)$ \\
\hline & Resistant & $f(x)=(81.0326(x)) /(0.11 * 614.8625+x)$ \\
\hline \multirow[t]{2}{*}{ 2C, metabolism } & Susceptible & $\begin{array}{l}f(x)=(100) \exp (-\exp (-0.618446(\log (x)- \\
58.015172)))\end{array}$ \\
\hline & Resistant & $\begin{array}{l}\mathrm{f}(\mathrm{x})=(100) \exp (-\exp (-0.749272(\log (\mathrm{x})- \\
13.595200)))\end{array}$ \\
\hline \multirow[t]{4}{*}{ 3A, metabolism } & $\begin{array}{l}\text { Susceptible, - } \\
\text { malathion }\end{array}$ & $\begin{array}{l}f(x)=((3.05020) /(1+\exp (1.13179(\log (x)- \\
\log (21.74716))))\end{array}$ \\
\hline & $\begin{array}{l}\text { Resistant, - } \\
\text { malathion }\end{array}$ & $\begin{array}{l}f(x)=((3.23644) /(1+\exp (1.16502(\log (x)- \\
\log (176.48644))))\end{array}$ \\
\hline & $\begin{array}{l}\text { Susceptible, }+ \\
\text { malathion }\end{array}$ & $\begin{array}{l}\mathrm{f}(\mathrm{x})=((3.15715) /(1+\exp (1.78556(\log (\mathrm{x})- \\
\log (22.74036))))\end{array}$ \\
\hline & $\begin{array}{l}\text { Resistant, }+ \\
\text { malathion }\end{array}$ & $\begin{array}{l}\mathrm{f}(\mathrm{x})=((3.18549) /(1+\exp (0.69062(\log (\mathrm{x})- \\
\log (24.42846))))\end{array}$ \\
\hline
\end{tabular}




\section{Supporting Information Materials and Methods}

\section{$\left[{ }^{14} \mathrm{C}\right]$ 2,4-D Absorption and Translocation}

In an first experiment at Kansas State University (KSU), 2,4-D-resistant and susceptible A. tuberculatus were grown in a greenhouse $\left(25 / 20^{\circ} \mathrm{C}\right.$ day/night temperature, $15 / 9 \mathrm{~h}$ day/night photoperiod). When the seedlings reached 5-6 cm tall, they were transferred to growth chambers maintained at $32.5 / 22.5^{\circ} \mathrm{C}, 15 / 9 \mathrm{~h}$ photoperiod, and $60-70 \%$ relative humidity. Light in the growth chamber was provided by fluorescent bulbs delivering $550 \mu \mathrm{mol} \mathrm{m} \mathrm{s}^{-1}$ photon flux at plant canopy level. Plants were watered as needed both under greenhouse and growth chamber conditions. Ten to $12 \mathrm{~cm}$ tall plants were treated with four $\times 2.5 \mu 1(3.33 \mathrm{kBq})$ droplets of $\left[{ }^{14} \mathrm{C}\right]$ 2,4-D on the adaxial surface of a fourth or fifth youngest leaf, which was marked with a black permanent marker. Unlabeled 2,4-D was added to the radioactive solution to obtain the field labeled rate of $280 \mathrm{~g} \mathrm{ha}^{-1}$ in a carrier volume of $187 \mathrm{~L} \mathrm{ha}^{-1}$. The adjuvants crop oil concentrate (COC, Agridex, Helena Holding Co., Wilmington, DE) and ammonium sulfate (AMS, Liquid NPaK; Agriliance, LLC, Inver Grove Heights, MN) were added at $1 \% \mathrm{v} / \mathrm{v}$ and $0.85 \% \mathrm{v} / \mathrm{v}$, respectively, to maximize adherence of herbicide solution to the leaf surface. The treated plants were returned to the same growth chamber. Plants were harvested at 6, 24, 48 and $72 \mathrm{~h}$ after treatment (HAT) and dissected into the tissue of treated leaf (TL), above the treated leaf (ATL), below the treated leaf (BTL), and roots (R). Treated leaves were rinsed for approximately $60 \mathrm{sec}$ with $5 \mathrm{ml}$ wash solution containing $10 \%$ methanol and $0.05 \%$ Tween $^{\mathrm{TM}}$ to remove any herbicide that was not absorbed. Liquid scintillation spectrometry (LSS; Tricarb 2100 TR Liquid Scintillation Analyzer; Packard Instrument Co., Meriden, CT) measured the amount of radioactivity in the leaf rinsate. The harvested samples were wrapped in a single layer of tissue paper and dried at $60^{\circ} \mathrm{C}$ for $16 \mathrm{~h}$. Subsequently, the plant samples were combusted using a 
biological oxidizer (OX-501, RJ Harvey Instrument, Tappan, NY) and radioactivity was determined via LSS. Total 2,4-D absorption was determined by the following equation: \% absorption $=($ total radioactivity applied - radioactivity recovered in wash solution $) \times 100 /$ total radioactivity applied. Herbicide translocation to each plant tissue was determined by the following equation: $\%$ absorbed $=($ radioactivity oxidized in plant tissue $/$ total radioactivity absorbed) $\times 100$. Total translocation was the sum of radioactivity recovered in ATL, BTL, and R.

$\left[{ }^{14} \mathrm{C}\right]$ Metabolism

In an experiment at KSU, 2,4-D-resistant and-susceptible common plants were grown as described previously for $\left[{ }^{14} \mathrm{C}\right] 2,4-\mathrm{D}$ absorption and translocation experiments. Ten to $12 \mathrm{~cm}$ tall plants were treated with $\left[{ }^{14} \mathrm{C}\right] 2,4-\mathrm{D}(3.99 \mathrm{kBq})$ as ten by $1 \mu \mathrm{L}$ droplets on the adaxial surface of fully expanded fourth and fifth youngest leaves. To remove any unabsorbed herbicide, the treated leaf was harvested and subsequently rinsed with $5 \%$ Tween $^{\mathrm{TM}}$ solution at 24,48 , and 72 HAT. All above ground plant tissue was immediately frozen in liquid nitrogen to prevent ongoing metabolism and then homogenized with mortar and pestle. $\left[{ }^{14} \mathrm{C}\right] 2,4-\mathrm{D}$ and its metabolites were extracted as described ${ }^{27}$ with minor modifications. Samples were centrifuged at $5,000 \times \mathrm{g}$ for $10 \mathrm{~min}$. Supernatants were extracted and concentrated for $2-3 \mathrm{~h}$ at $45^{\circ} \mathrm{C}$ until reaching an approximate final volume of $500 \mu \mathrm{l}$ (Centrivap, Labconoco, Kansas City, MO). The $500 \mu 1$ extract samples were transferred to $1.5 \mathrm{ml}$ microcentrifuge tubes and then centrifuged 10 $\min$ at $10,000 \times \mathrm{g}$. Total radioactivity per sample was measured via LSS. Samples were then normalized to $6,000 \mathrm{dpm}$ using acetonitrile:water $(50: 50, \mathrm{v} / \mathrm{v})$ prior to high-performance liquid chromatography (HPLC). 
Total extractable radioactivity in $50 \mu \mathrm{L}$ was resolved into parent $\left[{ }^{14} \mathrm{C}\right] 2,4-\mathrm{D}$ and its metabolites by reverse-phase HPLC (Beckman Coulter, System Gold, Brea, CA) following the protocol optimized previously in our laboratory ${ }^{27}$. Reverse-phase HPLC was performed with a Zorbax SB-C18 column $(4.6 \times 250 \mathrm{~mm}, 5-\mu \mathrm{m}$ particle size; Agilent Technologies $)$ at a flow rate of $1 \mathrm{~mL} \mathrm{~min}{ }^{-1}$. The radioactivity in the sample was measured using radio flow detector LB 5009 (Berthold Technologies). The metabolism experiment had three replicates for each treatment and the experiment was repeated. As the parent $\left[{ }^{14} \mathrm{C}\right] 2,4-\mathrm{D}$ had a retention time of $11.6 \mathrm{~min}$ in the KSU experiment, the radioactivity measured at this retention time was considered to be nonmetabolized $\left[{ }^{14} \mathrm{C}\right] 2,4-\mathrm{D}$. The percent non-metabolized $\left[{ }^{14} \mathrm{C}\right] 2,4-\mathrm{D}$ was calculated as the radioactivity measured at 11.6 min compared to total amount recovered.

\section{Data Analysis}

The experiments conducted at KSU were in randomized complete blocks and a single plant represented an experimental unit. Absorption and translocation experiments included four replications and experiments were conducted twice. The metabolism studies included three replications and were conducted twice. All data were analyzed using the PROC GLIMMIX procedure of SAS (SAS Institute Inc., Cary, NC 27513) for generalized linear mixed model analysis to incorporate normally distributed random effects. Variances were homogenous among individual runs within each experiment and thus runs were combined for analysis and presentation. Treatment means were separated by Fisher's protected least significant difference at $\mathrm{P} \leq 0.05$ level of significance. 
Supporting Information Table 2. Absorption (percentage of radioactivity applied) and translocation (percentage of absorbed radioactivity) of $\left[{ }^{14} \mathrm{C}\right]-2,4-\mathrm{D}$ in 2,4-D-resistant (R) and -susceptible (S) A. tuberculatus. Data are means with standard errors in parentheses from experiment conducted at Kansas State University. Means followed by different letters indicate significant differences.

\begin{tabular}{|c|c|c|c|c|c|c|}
\hline \multirow[b]{2}{*}{ Plant part } & \multicolumn{6}{|c|}{ Time after treatment } \\
\hline & Biotype & $6 \mathrm{~h}$ & $24 \mathrm{~h}$ & $48 \mathrm{~h}$ & $72 \mathrm{~h}$ & $96 \mathrm{~h}$ \\
\hline \multicolumn{7}{|c|}{${ }^{14} \mathrm{C}$ 2,4-D (as \% applied) } \\
\hline \multirow[t]{2}{*}{ Leaf rinse } & $\mathrm{R}$ & $63.22(2.73) \mathrm{a}$ & $47.65(3.04) \mathrm{a}$ & $51.02(2.59) \mathrm{a}$ & $49.39(3.57) \mathrm{a}$ & $43.87(2.21) \mathrm{a}$ \\
\hline & $\mathrm{S}$ & $59.51(0.84) \mathrm{a}$ & $45.59(3.55) \mathrm{a}$ & $48.69(2.89) \mathrm{a}$ & $49.17(3.30) \mathrm{a}$ & $41.88(2.95) \mathrm{a}$ \\
\hline \multirow[t]{3}{*}{ Total absorbed } & $\mathrm{R}$ & $36.77(2.73) \mathrm{a}$ & $52.34(3.04) \mathrm{a}$ & $48.97(2.59) \mathrm{a}$ & $50.61(3.57) \mathrm{a}$ & $56.12(2.21) \mathrm{a}$ \\
\hline & $\mathrm{S}$ & $40.49(2.44) \mathrm{a}$ & $54.40(3.55) \mathrm{a}$ & $51.30(2.89) \mathrm{a}$ & $50.82(3.30) \mathrm{a}$ & $58.11(2.95) \mathrm{a}$ \\
\hline & \multicolumn{5}{|c|}{${ }^{14} \mathrm{C} 2,4-\mathrm{D}$ recovered in plant (as \% absorbed) } & \\
\hline \multirow[t]{2}{*}{ Treated leaf (TL) } & $\mathrm{R}$ & $96.40(1.19) \mathrm{a}$ & $89.96(7.17) \mathrm{a}$ & $95.02(1.07) \mathrm{a}$ & $93.28(1.61) \mathrm{a}$ & $95.60(0.66) \mathrm{a}$ \\
\hline & $\mathrm{S}$ & $96.38(0.11) \mathrm{a}$ & $87.98(7.20) \mathrm{a}$ & $91.70(2.60) \mathrm{a}$ & 90.11 (1.77) a & $\begin{array}{r}92.46(2.35) \mathrm{a} \\
0.39(0.06) \mathrm{a}\end{array}$ \\
\hline \multirow[t]{2}{*}{ Shoot above (ATL) } & $\mathrm{R}$ & $0.59(0.19) \mathrm{a}$ & $0.85(0.33) \mathrm{a}$ & $0.91(0.22) \mathrm{a}$ & $0.67(0.12) \mathrm{a}$ & \\
\hline & $\mathrm{S}$ & $0.58(0.71) \mathrm{a}$ & $0.81(0.41) \mathrm{a}$ & $2.43(1.95) \mathrm{a}$ & $1.15(0.43) \mathrm{a}$ & $0.78(0.26) \mathrm{a}$ \\
\hline \multirow[t]{2}{*}{ Shoot below (BTL) } & $\mathrm{R}$ & $2.43(0.93) \mathrm{a}$ & $3.64(2.22) \mathrm{a}$ & $2.55(0.63) \mathrm{a}$ & $4.54(1.39) \mathrm{a}$ & $2.26(0.45) \mathrm{a}$ \\
\hline & $\mathrm{S}$ & $2.73(0.07) \mathrm{a}$ & $9.78(6.18) \mathrm{a}$ & $4.50(0.88) \mathrm{a}$ & $6.50(1.09) \mathrm{a}$ & $4.82(1.86) \mathrm{a}$ \\
\hline \multirow[t]{2}{*}{ Roots (BG) } & $\mathrm{R}$ & $0.55(0.15) b$ & $5.53(4.68) \mathrm{a}$ & $1.51(0.41) \mathrm{a}$ & $1.50(0.37) b$ & $1.73(0.33) b$ \\
\hline & $\mathrm{S}$ & $0.41(0.07) \mathrm{a}$ & $1.40(0.64) b$ & $1.35(0.51) b$ & $2.22(0.73) \mathrm{a}$ & $1.93(0.30) \mathrm{a}$ \\
\hline Total translocated & $\mathrm{R}$ & $3.59(1.20) \mathrm{a}$ & $10.03(7.17) \mathrm{a}$ & $4.98(1.07) \mathrm{a}$ & $6.72(1.62) \mathrm{a}$ & $4.39(0.67) \mathrm{a}$ \\
\hline$(\mathrm{ATL}+\mathrm{BTL}+\mathrm{BG})$ & $\mathrm{S}$ & $3.62(0.84) \mathrm{a}$ & $12.01(7.20) \mathrm{a}$ & $8.30(2.60) \mathrm{a}$ & $9.89(1.78) \mathrm{a}$ & $7.53(2.36) \mathrm{a}$ \\
\hline
\end{tabular}


Supporting Information Table 3. Least square means and ANOVA of percent parent compound $\left[{ }^{14} \mathrm{C}\right]$ 2,4-D remaining in resistant and susceptible $A$. tuberculatus populations $(\mathrm{P})$ at three harvest $(\mathrm{H})$ timings from experiment conducted at Kansas State University.

\begin{tabular}{ccc}
\hline & \multicolumn{2}{c}{$\begin{array}{c}\text { Parent Compound }\left[{ }^{14} \mathrm{C}\right] 2,4-\mathrm{D}^{*} \\
(\%)\end{array}$} \\
\cline { 2 - 3 } Harvest & Resistant & Susceptible \\
\hline 24 HAT & 47.8 & 84.3 \\
48 HAT & 29.4 & 57.2 \\
72 HAT & 33.6 & 53.3 \\
\hline ANOVA & \multicolumn{2}{|}{} \\
\hline P & \multicolumn{2}{|c}{$<0.0001$} \\
H & \multicolumn{2}{c}{0.0004} \\
P by H & \multicolumn{2}{c}{0.3609} \\
\hline
\end{tabular}

*Analysis of variance using PROC GLIMMIX in SAS 2013 using Fisher's Protected LSD at P $\leq$ 0.05 level of significance. Values reflect three replications and two runs. Each plant received $3.98 \mathrm{kBq}$ of radiation. 